mates savings in the millions of dollars for the several projects through handling the books centrally. The savings are made through ordering and processing many copies of the same book at one time, through use of computers, and through the larger discount realized in large bulk purchasing.

Another benefit is that book dealers and publishers have been much more reliable in filling mass orders than in filling the typical order for one or a few copies of a book at a time.

Assembly-line procedures under Kennedy's direction provide the clockwork operation required to keep 2,500 volumes arriving daily and another 2,500 being shipped out. Each college receives at least one box of $30-40$ books most days, complete with book cards, pockets, and labels. The cooperative efforts of the Board of Higher Education, the chief librarians, and the University of Massachusetts library have created a uniquely valuable service for public higher education in Massachusetts.

\section{ACRL NOMINEES 1971/72}

(For other nominees, see CRL News, February 1971.)

\section{Subject Specialist Section}

Vice-chairman (Chairman-elect)

Alice Dulany Ball, United States Book Exchange, Inc., Washington, D.C.

Janet C. Price, Bureau of Library Extension, Department of Education, Commonwealth of Massachusetts, Boston, Mass.

Law and Political Science Subsection

Vice-chairman (Chairman-elect)

Judy H. Fair, The Stanford University Libraries, Stanford, Calif.

Roy H. Fry, Loyola University, Chicago, Ill.

Member-at-Large

Jennie B. Cross, Oakland University, Rochester, Mich.

Michael Shannon, Herbert Lehman College, Bronx, N.Y.

Asian and North African Subsection

Vice-chairman (Chairman-elect)

Adrian Jones, Roosevelt University, Chicago, Ill.

Theodore Welch, Northwestern University, Evanston, III.

\section{Member-at-Large}

Charles R. Bryant, Yale University, New Haven, Conn.

Lee S. Dutton, Northern Illinois University, De Kalb, Ill.
PRECONFERENCE INSTITUTE UNIVERSITY LIBRARIES SECTION

"Librarians Confront the New Undergraduate Environment" will be the theme of a twoday institute held on June 18 and 19, 1971, prior to the Annual Conference of the American Library Association in Dallas. The sponsor of the institute is the University Libraries Section of the Association of College and Research Libraries.

The objectives of the institute are to (I) consider the evolving character of academic institutions; (2) develop a perspective for understanding students and faculty; (3) discuss innovative programs for undergraduates; and (4) stimulate active undergraduate librarianship. Directed toward university and college librarians, the institute will examine critical issues dealing with the undergraduate environment, including the character of contemporary undergraduates, new trends in undergraduate programs, and attitudes of faculty toward change in undergraduate education.

Two basic approaches to undergraduate library service will also be discussed. One session will be devoted to service programs which reach out directly to students. A second session will evaluate active service programs designed to serve undergraduates by working through the faculty and the curriculum.

Program participants include James Davis, College Librarian, UCLA; Thelma Fredis, Associate Professor, School of Library Service, Atlanta University; James Gibbs, Jr., Dean of Undergraduate Studies, Stanford University; Joseph Gusfield, Professor and Chairman, Department of Sociology, University of California, San Diego; John Haak, Institute Chairman and Undergraduate Librarian, University of California, San Diego; Paul Heist, Research Psychologist and Professor of Education, Project for Research in Undergraduate Education, University of California, Berkeley; Patricia Knapp, Associate Professor, Department of Library Science, Wayne State University; and George Bonham, Editor-in-Chief, Change Magazine.

The institute is limited to 250 persons. For application forms and further information write ULS/ACRL Preconference Institute, c/o Executive Secretary, Association of College and Research Libraries, 50 East Huron Street, Chicago, Illinois 60611 .

ACRL Membership

February 28, 1971

February 28, 1970

12,796

February 28, 1969 